\title{
Evaluation of Some Inflammatory and Biochemical Markers in Obese and Lean Iraqi Women
}

\author{
Farah T. O. Al-Jumaili \\ Department of Biotechnology, College of Science, Al-Nahrain University, Baghdad-Iraq. \\ E-mail:Farahbio@yahoo.Com.
}

\begin{abstract}
The present study aims to detecting several biochemical markers and cytokines in obese and normal lean Iraqi women. Forty women $(r \cdot$ obese and $r \cdot$ lean) were chosen from different areas in Baghdad city there ages ranges between $r \cdot-r V$ years and body mass index (BMI) between $r_{\cdot}, \vee_{O_{-}} r_{0}, r_{\mathrm{Kg}} / \mathrm{m}^{2}$. The study showed a high significant increment in Fasting Blood Glucose (FBG), serum cholesterol and Homeostasis Model Assessment (HOMA) in obese women as compared with lean and a significant increment in HDL (High Density Lipoprotein) in lean women when compared with obese ones. A significant correlation coefficient (r) was noticed between BMI and studied parameters, FBG, cholesterol, triglyceride, insulin, HOMA, high sensitive C Reactive Protein

(hs-CRP), Tumor Necrosis Factor alfa (TNF- $\alpha$ ) and IL- 7 .
\end{abstract}

Keywords: Obesity. BMI, Cholesterol, Inflammatory Mediator.

\section{Introduction}

Obesity is a medical condition in which excess body fat has accumulated to the extent that it may have an adverse effect on health, leading to reduced life expectancy and/or increased health problems $[1, Y]$ Obesity increases the likelihood of various diseases, particularly heart disease, type $r$ diabetes, obstructive sleep apnea, certain types of

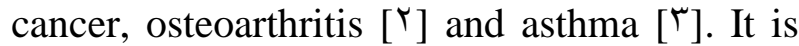
most commonly caused by a combination of excessive food energy intake, lack of physical activity, and genetic susceptibility, although a few cases are caused primarily by genes. Obesity is defined by body mass index (BMI) and further evaluated in terms of fat distribution via the waist-hip ratio and total cardiovascular risk factor $[\varepsilon, 0]$. BMI is closely related to both percentage body fat and total body fat [ [ ] . As a result, obesity has been found to reduce life expectancy [r]. At an individual level, a combination of excessive food energy intake and a lack of physical activity is thought to explain most cases of obesity [ $\mathrm{V}]$. A limited number of cases are due primarily to genetics, medical reasons, or psychiatric illness[^].In contrast, increasing rates of obesity at a societal level are felt to be due to an easily accessible and palatable diet $[9]$ increased reliance on cars, and mechanized manufacturing $[1,, 11]$. Obesity is one of the leading preventable causes of death world wide Large scale $[\wedge,|r| r$,$] . American and$ European studies have found that mortality risk is lowest at a BMI of $r \cdot-r_{0} \mathrm{~kg} / \mathrm{m}^{r}$, in non-smokers $[1 \leqslant, 10]$ and at $r \leqslant-r V \mathrm{~kg} / \mathrm{m}^{r}$ in current smokers, with risk increasing along with changes in either direction. $[17,1 \mathrm{~V}]$. A BMI above ${ }^{r} r \mathrm{~kg} / \mathrm{m}^{r}$ has been associated with a doubled mortality rate among women over a 17-year period[ $\mid \wedge]$. In the United States obesity is estimated to cause $111,9.9$ to r.o,... deaths per year $[r, 1$,$] , while 1$ million $(\vee, \vee \%)$ of deaths in Europe are attributed to excess weight $[19, r \cdot]$. On average, obesity reduces life expectancy by six to seven years $[r, r)]$. BMI of $r \cdot-r o \mathrm{~kg} / \mathrm{m}^{r}$ reduces life expectancy by two to four years $\left[{ }^{0}\right]$, while severe obesity $\left(\mathrm{BMI}>\leqslant \cdot \mathrm{kg} / \mathrm{m}^{r}\right)$ reduces life expectancy by ten years [10]. Complications are either directly caused by obesity or indirectly related through mechanisms sharing a common cause such as a poor diet or a sedentary lifestyle. The strength of the link between obesity and specific conditions varies. One of the strongest is the link with type $r$ diabetes. Excess body fat underlies $\tau \leqslant \%$ of cases of diabetes in men and $\checkmark v \%$ of cases in women [rr]. Health consequences fall into two broad categories: those attributable to the effects of increased fat mass (such as osteoarthritis, obstructive sleep 
apnea, social stigmatization) and those due to the increased number of fat cells (diabetes, cancer, cardiovascular disease, non-alcoholic fatty liver disease) $[r, r r]$. Increases in body fat alter the body's response to insulin, potentially leading to insulin resistance. Increased fat also creates a proinflammatorystate $\left[r \varepsilon, r_{0}\right]$ and a prothrombotic state[rr, $\left.Y^{\top}\right]$ ]. This studied aimed to matured some inflammatory and Biochemical parameter and compared results between lean and obese women.

\section{Experimental Work Patients}

The study groups included forty women $r$. obeseand $r$. lean control. Women were chosen randomly according to their weight, their ages ranged $r \cdot-r v$ years, The controls were selected among subjects who were healthy in terms of regular cycle, normal hormonal assay, non-diabetic, nonhypertensive, no other endocrine disorders and were free of acute illness or infection at time of sampling. In all cases, body weight and height, BMI were measured by using standard methods. All cases were investigated for the Serum levels of insulin, cytokines (IL- 7 and TNF- $\alpha$ ), high sensitive $\mathrm{C}$-Reactive protein in addition to plasma level of glucose and Lipid profile From each cases, 1. $\mathrm{ml}$ of blood were obtained by venepuncture, using a $1 . \mathrm{ml}$ disposable syringe between $9, \ldots$ and $11, \cdots$ A.M. The blood sample was divided into two aliquots; $r$ and $V_{\mathrm{ml}}$. the first aliquot was used for the estimation of plasma glucose and lipid profile. The second aliquot was dispensed in a plain tube and left for an hour to clot at room temperature $r^{r}{ }^{\circ} \mathrm{C}$, and then centrifuged at r... rpm for $1 \cdot$ minutes to collect serum. The serum was divided into aliquots $\left(r^{\circ} \cdot \mu l\right)$ in Eppendorff tubes and stored in the freezer at $r \cdot{ }^{\circ} \mathrm{C}$ until use.

\section{Measurements of Markers}

* Serum TNF- $\alpha$ concentration was determined by the sandwich ELISA method (Phoenix Pharmaceuticals, INC, USA).
Serum IL- 7 concentration was determined by the competitive ELISA method (Raybiotech Company, USA).

- Serum hs-CRP concentration was determined by the competitive ELISA method (Demedetec Company, Germany).

* Serum insulin concentration was determined by the sandwich ELISA method Serum (Demedetec Company, Germany).

- Cholesterol level was measured by enzymatic end point method supplied by (Bio Labo Company, Franc).

* Triglyceride was determined after enzymatic hydrolysis with lipase into fatty acids and glycerol. The resultant glycerol is then phosphorelatedin the presence of ATP and glycerokinase to give hydrogen peroxide that react in presence of peroxidase with $\varepsilon_{-}$ aminoantipyrine and parachlorophenol to give colored chromophen equinoneimie (Bio Labo Company, Franc).

* Low-density lipoprotein-cholesterol was estimated by using formula of Friedwald $[r v]$.

\section{LDL - cholesterol $=$ Total cholesterol -} [HDL-cholesterol + TG/ ${ }^{\bullet}$ ]

Very low-density lipoprotein- cholesterol was estimated by using formula of Friedwald [rv].

\section{VLDL-Cholesterol $=\mathbf{T G} / \stackrel{\bullet}{ }$}

Insulin resistance (IR) was determined by a number of different methods including fasting insulin, glucose for calculation (insulin measured $\mu \mathrm{U} / \mathrm{ml}$, glucose measured in $\mathrm{mg} / \mathrm{dl}$ ), the homeostasis model assessment (HOMA). The estimation of insulin resistance by HOMA score was calculated using Matthews formula $\left[{ }^{\top} \wedge\right]$.

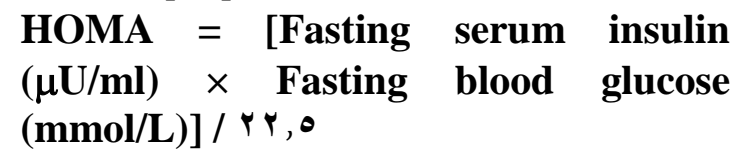

\section{Statistical Analysis}

Results were analysed using Statistical Analysis System- SAS ( $r \cdot 1 \cdot)$ T-test was used to significant compared between means. Correlation coefficient was estimated. 
Journal of Al-Nahrain University Science

\section{Results and Discussion}

In the present study, groups were divided in two dependent on BMI obese and lean to note the effect of obesity on the studied factors.

\section{Table ( ')}

Inflammatory and biochemical markers in Obese and Lean Iraqi women.

\begin{tabular}{|c|c|c|c|}
\hline $\begin{array}{c}\text { Parameters } \\
\text { studied }\end{array}$ & Lean & Obese & $\begin{array}{l}\text { Level } \\
\text { of Sig. }\end{array}$ \\
\hline TNF- $\alpha$ & $r, r r_{ \pm} \cdot, \lambda r$ & $r, V Y \pm 1, \cdot V$ & NS \\
\hline IL-7 & $11, V Y_{ \pm} 7,9 V$ & $10, r q_{ \pm} 7,0$ & NS \\
\hline hs-CRP & $1, \wedge 9 \pm 1, \vee 0$ & $r, V r \pm 1,19$ & $\mathrm{NS}$ \\
\hline $\begin{array}{l}\text { Fasting } \\
\text { Serum } \\
\text { Insulin }\end{array}$ & $\mid r, r \cdot \pm 1, \wedge$ & $1 \leq, 00 \pm r, r_{0}$ & NS \\
\hline Triglyceride & $\begin{array}{c}111,00 \pm 11,1 \\
r\end{array}$ & $\begin{array}{c}r, V \cdot \pm 1 q, V \\
q\end{array}$ & NS \\
\hline HDL & $70, Y 0_{ \pm} 9,1 V$ & $0 \Lambda, r \sigma_{ \pm} \mid r, Y r$ & "* \\
\hline VLDL & $r r, 9 \leq \pm \varepsilon, 11$ & $r r, \mid V_{ \pm} \varepsilon, r \varepsilon$ & NS \\
\hline $\begin{array}{l}\text { Serum } \\
\text { Cholesterol }\end{array}$ & $\begin{array}{c}V \cdot, V \cdot \pm 11,7 \\
\varepsilon\end{array}$ & $\begin{array}{c}\mid \wedge 7,1 \cdot \pm 1 \cdot, \varepsilon \\
V\end{array}$ & $* *$ \\
\hline FBG & $V V, V \cdot \pm \cdot, \cdot V$ & $\wedge q, \vee \Delta_{ \pm} \Gamma \cdot, \cdots$ & *** \\
\hline HOMA & $\varepsilon r, r V_{ \pm} \wedge, \cdot \cdot 1$ & $0 \vee, \wedge V_{ \pm} \mid r, 1 \cdot$ & *** \\
\hline
\end{tabular}

$*(P \leq \bullet, \bullet), * *(P \leq \bullet, \cdot 1)$, NS: Non-significant.

The mean serum level of Tumor Necrosis Factor- $\alpha$ (TNF- $\alpha)$ was non significantly elevation between lean $\left(r, r r_{ \pm}, \wedge r \mathrm{pg} / \mathrm{ml}\right)$ and obese once $(Y, V Y \pm 1, \cdot \vee \mathrm{pg} / \mathrm{ml})$, in serum Interleukin- 1 (IL- 7 ) the mean values $\left(11, V Y_{ \pm} \tau, 9 \vee \mathrm{pg} / \mathrm{ml}\right)$ for lean and $\left(10, r q_{ \pm} \tau, .0 \mathrm{pg} / \mathrm{ml}\right)$ for obese found to be non-significantly elevated, it was also for Serum High sensitive C-Reactive Protein (hsCRP) found to be non-significantly elevated in obese $\left(r, V r_{ \pm}, 19 \mathrm{mg} / \mathrm{L}\right)$ witha mean of $\left(1, \wedge q_{ \pm}, \vee \vee \circ \mathrm{mg} / \mathrm{L}\right)$ in lean women, Fasting serum insulin showed non-significant results between lean $(\mid r, \tau \cdot \pm 1, \cdot \wedge \mu \mathrm{U} / \mathrm{ml})$ and obese once $\left(\mid \leqslant, 00_{ \pm} r, \Gamma \circ \mu \mathrm{U} / \mathrm{ml}\right)$, in Triglyceride there was no significant in lean women (1) $11,00 \pm / \Lambda, 1 \mathrm{rmg} / 1 \cdots \mathrm{ml}$ ) when it compared with obese once $(\mid r r, V \cdot \pm 19, \vee q \mathrm{mg} / l \cdots \mathrm{ml})$, in High Density Lipoprotein (HDL) there was a significant increase in lean women $\left(70, Y 0_{ \pm} q, \mid \vee \mathrm{ml} / \mathrm{dl}\right)$ when compared with obese once $\left(0 \wedge, r \sigma_{ \pm} l r, r r \mathrm{ml} / \mathrm{dl}\right)$, there was no significant increase in Very Low Density Lipoprotein (VLDL) between lean women $\left.\left(Y r, q \varepsilon_{ \pm} \varepsilon, 1\right) \mathrm{mg} / \mathrm{dl}\right)$ when it compared with obese once $\left(r r, \mid V_{ \pm} \varepsilon, r \varepsilon \mathrm{mg} / \mathrm{dl}\right)$, there was a significant increments in serum cholesterol in obese women $(|\wedge \mathrm{\wedge},| \cdot \pm|\cdot, \Sigma \vee \mathrm{mg} /| \cdots \mathrm{ml})$ when it compared with lean once $(\mid \vee \cdot, v \cdot \pm l 1,7 \varepsilon)$, also there was a significant increments in Fasting Blood Glucose (FBG) in obese women $\left(\wedge q, \vee \vee_{ \pm} r \cdot, \cdots \mathrm{mg} / \mathrm{dl}\right)$ when it compared with lean once, and there was a significant increment in Homeostasis Model Assessment (HOMA) in obese women $\left(\Delta \vee, \wedge \vee_{ \pm} \mid r, l \cdot\right)$ when it compared with lean once( $\left\{r, r V_{ \pm} \Lambda, \cdot 1\right)$.

\section{Correlation coefficient (r) between BMI and studied parameters}

A significant correlation was found between BMI among FBG, Cholesterol, Triglyceride, HOMA, insulin, hs-CRP, TNF- $\alpha$, IL- $\uparrow$ as shown in Table $(r)$.

Table (')

Correlation coefficient (r) between BMI and studied parameters.

\begin{tabular}{|c|c|c|}
\hline $\begin{array}{c}\text { Parameters } \\
\text { studied with } \mathrm{BMI} \\
\end{array}$ & $\begin{array}{l}\text { Correlation } \\
\text { coefficient } \\
\end{array}$ & Level. of sig. \\
\hline FBG & $\cdot, \varepsilon Y$ & $* *$ \\
\hline Cholesterol &., $0 \mathrm{~V}$ & *** \\
\hline Triglyceride & • & ** \\
\hline HDL & $-\cdot, Y \leq$ & NS \\
\hline VLDL & $\cdot, \cdot \varepsilon$ & NS \\
\hline Insulin & $\cdot, Y \wedge$ & * \\
\hline HOMA & $\cdot, \leqslant 1$ & $* *$ \\
\hline hs-CRP & $\cdot, \leqslant 1$ & $* *$ \\
\hline TNF- $\alpha$ & $\cdot, \Sigma Y$ & *** \\
\hline IL-7 & $\cdot, \varepsilon$. & *** \\
\hline
\end{tabular}

* $(\boldsymbol{P} \leq \bullet \cdot \bullet \bullet), * *(P \leq \bullet, \bullet)$, NS: Non-significant

The concentration of HDL-cholesterol is adversely altered in obesity, with HDLcholesterol levels associated with both the degree and distribution of obesity. More specifically, intra - Abdominal visceral fat deposition is an important negative correlate of HDL-cholesterol. The specific subfractions of HDL that are altered in obese states include the HDL ${ }^{r}$, apolipoprotein A-I, and pre-beta) subfractions. Decreased HDL levels in obesity have been attributed to both an enhancement in the uptake of HDL $r$ by adipocytes and an increase in the catabolism of apolipoprotein A-I on HDL particles. In addition, there is a decrease in the conversion of the pre-betal subfraction, the initial acceptor of cholesterol from peripheral cells, to pre-betar particles $\left[{ }^{q}\right]$ ]. Obesity is at epidemic levels in all age groups. The effect of obesity on cholesterol levels is complex. Overweight individuals 
tend to have high triglyceride and LDL levels and low HDL levels. This combination is a risk factor for heart disease, Obesity also causes other effects (high blood pressure, increase in inflammation) that pose major risks to the heart. Darvall and his research team reported that increased levels of both triglycerides and free fatty acids are associated with obesity and insulin resistance $[r \cdot]$.

Obesity is particularly dangerous when it is one of the components of the metabolic syndrome, formerly known as syndrome $\mathrm{X}$. This syndrome consists of obesity marked by abdominal fat, unhealthy cholesterol levels, high blood pressure, and insulin resistance. Metabolic syndrome is a pre-diabetic condition that is significantly associated with heart disease and higher mortality rates from all causes. Many doctors recommend that patients with metabolic syndrome should be aggressively treated with high-dose statin therapy to lower LDL levels. Obesity is also strongly associated with type $r$ diabetes, which itself poses a significant risk for high cholesterol levels and heart disease $[r \cdot]$.

A higher BMI is associated with higher homeostasis model assessment values for insulin resistance (HOMA-IR), homeostasis model assessment of $\beta$-cell function (HOMA- $\beta$ ), and insulinogenic index as well as lower levels of insulin sensitivity index composite (ISI $\mathrm{I}_{\text {comp }}$ ) and disposition index (DI) [ri].

These changes are consistent with the lipid profile that is typically found in association with insulin resistance. The effects of insulin resistance on lipid metabolism are well known. Increased secretion of very lowdensity lipoprotein (VLDL) particles by the liver results in elevated plasma TG concentrations. Subsequently, TGs are exchanged for cholesteryl ester (CE) by the activity of CE transfer protein. This process results in TG-enriched high-density lipoprotein (HDL) particles that are catabolized more rapidly, and CE-enriched VLDL particles that are converted into small dense low-density lipoprotein (LDL) particls $\left[{ }^{r}\right]$. As a consequence, insulin resistance contributes to decreased plasma levels of HDL-C and apolipoprotein (apo) A-I, and higher levels of apo B [ $\left.{ }^{\mu}\right]$.
The HOMA is a method for assessing $\beta$ cell function and IR from fasting glucose and insulin or C-peptide concentrations. The relationship between glucose and insulin in the basal state reflects the balance between hepatic glucose output and insulin secretion, which is maintained by a feedback loop between the liver and B-cells [ $\left.{ }^{\Gamma} \varepsilon\right]$. Decreases in $B$-cell function were modeled by changing the $\beta$-cell response to plasma glucose concentrations. Insulin sensitivity was modeled by proportionately decreasing the effect of plasma insulin concentrations at both the liver and the periphery [r<]. Some investigators had recommended calculating an index of IR from glucose and insulin levels (e.g. HOMA) [ro]. In previous study HOMA was considered as valid method to assess insulin sensitivity in epidemiological studies [rד].

Cytokines such as TNF- $\alpha$ influence several metabolic activities, including glucose and lipid metabolism [ ${ }^{r} v$ ]. Since obesity and IR are frequent findings in hyper androgenic women in the current study, TNF- $\alpha$ concentration were positively correlated with BMI, as shown in table $r$. Previous studies have shown the relationship between BMI and TNF- $\alpha$ level [r^, $r q]$.

The secretion of $\mathrm{IL}^{-} 7$ is regulated by several physiologic or pathologic factors: hormones, cytokines, diet, physical activity, stress, hypoxia, and others. Adipose tissuederived IL- ${ }^{\top}$ may have an effect on metabolism through several mechanisms, including adipose tissue-specific gene expression, triglyceride release, lipoprotein lipase down regulation, insulin sensitivity, and so on $[\varepsilon \cdot]$.

IL- 7 is believed to be beneficial for insulin-regulated glucose metabolism in muscle. Furthermore, the effects of the cytokine are seemingly influenced by whether it is present acutely or chronically; the latter is the setting associated with insulin resistance [₹)].

\section{Conclusion}

In the present study, there was a significant increment in Fasting Blood Glucose (FBG), serum cholesterol and Homeostasis Model Assessment (HOMA) in obese womens as compared with lean once 
Journal of Al-Nahrain University Science

and a significant increment in HDL (High Density Lipoprotein) in lean womens when compared with obese once. A significant correlation coefficient ( $r$ ) was noticed between BMI and studied parameters, FBG, cholesterol, triglyceride, insulin, HOMA, high sensitive C Reactive Protein (hs-CRP), Tumor Necrosis Factor alfa (TNF- $\alpha$ ) and IL- 7 .

\section{References}

[1] WHO, $\mathrm{p}^{\urcorner}, \mathrm{r} \cdots$.

[ץ] Haslam D W, James WP, "Obesity"

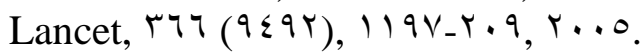

[r] Poulain M, Doucet M, Major G, et al "The effect of obesity on chronic respiratory diseases: pathophysiology and therapeutic

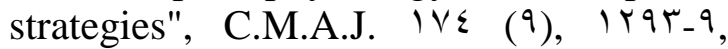
Y.. T.

[₹] Sweeting $\mathrm{H} \quad \mathrm{N}$ "Measurement and Definitions of Obesity In Childhood and Adolescence: A field guide for the uninitiated", Nutr. J. 7 ( ( ), r r, Y .. V.

[0] NHLBI, p.xiv, r. Ir.

[?] Gray D, Fujioka K, "Use of relative weight and Body Mass Index for the determination of adiposity", J. Clin. Epidemiol. $\leqslant \leqslant(7), 0 \leqslant 0-0 \cdot, 1991$.

[₹] Lau D C, Douketis J D, Morrison K M, HramiakI M, Sharma A M, Ur E, "ץ.. Canadian clinical practice guidelines on the management and prevention of obesity in adults and children summary", C.M.A.J. IVฯ (ᄉ), S I-Ir, Y... .

[^] Bleich S, Cutler D, Murray C, Adams A, "Why is the developed world obese?", Annu. Rev. Public Health, $r q, r \vee r-90$, r...v.

[9] Drewnowski A, Specter S E, "Poverty and obesity: the role of energy density and energy costs", Am. J. Clin. Nutr. $\vee १(1), 7$. $17, Y \ldots \varepsilon$.

[1·] Nestle M, Jacobson M F, "Halting the obesity epidemic: a public health policy approach", Public Health Rep, 110 (1), I Y $-Y \leqslant, Y \ldots$.

[1'] James W P, "The fundamental drivers of the obesity epidemic", Obes Rev, 9 (Suppl

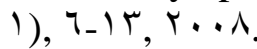

[I ] Mokdad A, Marks J, Stroup D, Gerberding J, "Actual causes of death in the United States, Y...", J.A.M.A. Yq)

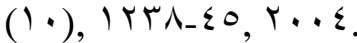

[1 $\left.{ }^{\mathrm{T}}\right]$ Allison D, Fontaine K, Manson J, Stevens J, VanItallie T, "Annual deaths attributable to obesity in the United States", J.A.M.A. rAr (17), 10r.-A, 1999.

[1 $\varepsilon$ ] Berrington D, Gonzalez A, "Body-Mass Index and Mortality among 1, $\leqslant 7$ Million White Adults", N. Engl. J. Med. Tr ז (Yr), rYll-9, r. . .

[10] Whitlock G, Lewington S, Sherliker P, et al "Body-mass index and cause-specific mortality in $9 \ldots .$. adults: collaborative analyses of ov prospective studies", Lancet, rVT (9779), 1.人r-97, Y.. . .

[1 1 ] Calle E, Thun M, Petrelli J, Rodriguez C, Heath C, "Body-mass index and mortality in a prospective cohort of U.S. adults", N. Engl. J. Med. r $\left.\leqslant 1(10), 1.9 V_{-}\right)$. 0, 1999.

[ $\mathrm{V}$ ] Pischon T, Boeing H, Hoffmann K, et al "General and abdominal adiposity and risk of death in Europe" N. Engl. J. Med. r०१ $(r \cdot), r) \cdot 0_{-} r \cdot, r \cdots \Lambda$.

['^] Manson J, Willett W, Stampfer M, et al "Body weight and mortality among women" N. Engl. J. Med. זrז (1), TVV_ 10, 1990 .

[19] Tsigosa C, Hainer V, Basdevant A, Finer N, Fried M, Mathus-Vliegen, E, Micic D, Maislos M, Roman G, "Management of Obesity in Adults: European Clinical Practice Guidelines", The European Journal of Obesity, ' (r),,$\left.\cdot r_{-}\right), r_{\ldots} \cdot \wedge$

$\left[r^{\cdot}\right]$ Fried M, Hainer V, Basdevant A, et al "Inter-disciplinary European guidelines on surgery of severe obesity", Int. J. Obes.

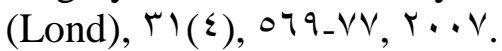

[r)] Peeters A, Barendregt J, Willekens F, Mackenbach J, Al Mamun A, Bonneux L, "Obesity in adulthood and its consequences for life expectancy: A lifetable analysis" (PDF). Ann. Intern. Med.

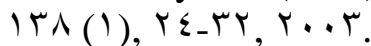

$[r r]$ Seidell, p. ${ }^{q}, r \ldots o$.

$\left[r^{r}\right]$ Bray G, "Medical consequences of obesity", J. Clin. Endocrinol. Metab. $\wedge 9$ (?). ro人r-q, r...

[Y $\left.{ }^{Y}\right]$ Shoelson S, Herrero L, Naaz A,"Obesity, inflammation, and insulin resistance" Gastroenterology 1 r $r(\uparrow), r / 7 q \_\wedge \cdot, r \cdots \vee$.

[ro] Shoelson S, Lee J, Goldfine A, "Inflammation and insulin resistance", J. Clin. Invest. $\left.117(\vee), 1 \vee 9 r_{-} \wedge .1, Y \ldots\right\urcorner$. 
[Yฯ]Dentali F, Squizzato A, Ageno W, "The metabolic syndrome as a risk factor for venous and arterial thrombosis" Semin.

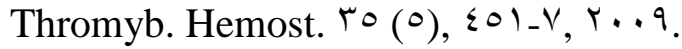

$[r V]$ Friedewald W, Levy R, Fredrickson D, "Estimation of the concentration of lowdensity lipoprotein cholesterol in plasma without use of the ultracentrifuge", Clin. Chem. I^, $\leqslant \leqslant 9-0 . r, 19 \vee r$.

[r/] Matthews D, Hosker J, Rudenski A, Naylor B, Treacher D, Turner R, "Homeostasis model assessment: insulin resistance and beta-cell function from fasting plasma glucose and insulin concentrations in man", Diabetologia, $r \wedge$, ₹1 $Y_{-} \leqslant 19,1910$.

[ ${ }^{9}$ ] Rashd S, Genest J, "Effect of obesity on high-density lipoprotein metabolism. Obesity" (Silver Spring), 1०( I Y ), Y $\wedge \mathrm{O}_{-} \wedge \Lambda$, r...v.

$[r \cdot]$ Simon M D, "High Blood Cholesterol Levels", Depth Report, $r \cdot I r$.

[r']Jin O, Dong H, Dong J, and Min Y, "Associations among Body Mass Index, Insulin Resistance, and Pancreatic $\beta$-Cell Function in Korean Patients with NewOnset Type $r$ Diabetes" Diabetes Res. Clin. Pract. $r V(1), 77-V 1, Y \cdot I r$.

[rr]Barter P J, Brewer J R, Chapman M J, Hennekens C H, Rader D J, Tall A R, "Cholesteryl ester transfer protein: a novel target for raising HDL and inhibiting atherosclerosis", Arterioscler Thromb. Vasc. Biol. Yr, 1 $7 \cdot-17 V$, Y..r.

$[r \pi]$ Taskinen M R, "LDL-cholesterol, HDLcholesterol or triglycerides-which is the culprit? Diabetes", Res. Clin. Pract. 7 ( ( ), S) 9-SYT, r..r.

[ $r \varepsilon]$ Turner R, Holman R, Matthews $D$, Hockaday T, Peto J, "Insulin deficiency and insulin resistance interaction in diabetes: estimation of their relative contribution by feedback analysis from basal plasma insulin and glucose concentrations", Metabolism, $r \wedge, 1 \cdot \wedge \tau_{\text {_ }}$ $1.97,19 \vee 9$.

[ro] Abassi F, Reaver G, "Evaluation of the quantitative insulin sensitivity index as an estimate of insulin sensitivity in humans", Metabolism, 01, rro_rrv, r..r.

[ץч]Bonora E, Kiechl S, and Willeit J, "Prevalence of insulin resistance in metabolic disorder: the Bruneck study", Diabetes, $\leqslant \vee, 17 \leqslant r-17 \leqslant 9,199 v$.

[rV]I'lhan T, Berrin C, Erdem T, Zeynep C, Mithat B, "Association between circulating tumor necrosis factor-alpha, interleukin- 7 , and insulin resistance in normal-weight women with polycystic ovary syndrome", Metabolic syndrome and related disorders, $\varepsilon(r),\left|r_{-}\right| r \wedge$, r... T.

[广^] Isakson P, Hammarstedt A, Gustafson B, Smith U, "Impaired preadipocyte differentiation in human abdominal obesity role of Wnt, TNF\{alpha\} and inflammation", diabetes, $|\mathrm{V} \vee \mathrm{V}|$ $|V V \cdot V| \cdot, Y \cdot q$.

[rq] Orio F, Palomba $S$, Cascella $T$, Tauchmanovà L, Nardo L, Di Biase S, Labella D, Russo T, Savastano S, Tolino A, Zullo F, Colao A, Lombardi G, "Is plasminogen activator inhibitor-1 a cardiovascular risk factor in young women with polycystic ovary syndrome", Reprod Biomed Online, $)^{\cdot},(r), r \wedge q, r \ldots o$.

$[\varepsilon \cdot]$ Katalin E, Noemi B, Andras F, and Andras K, "The major inflammatory mediator interleukin- 7 and obesity", Inflammation Research, o^, (1), VYV$\vee r 4, Y \ldots q$.

[₹1] Kim, and Chen J, "Interleukin- 7 and insulin resistance", Vitam. Horm. $\left.\Lambda_{\cdot}, 7\right) r$ rr, r... .

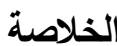

استهدفت الدراسة تحديد تراكيز بعض الهرمونات

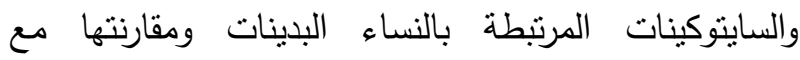

مجموعة النساء النحيفات الطبيعيات نم اختيار (•ـ) امراة

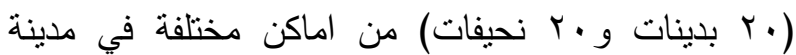

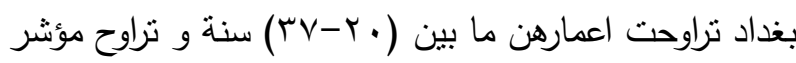

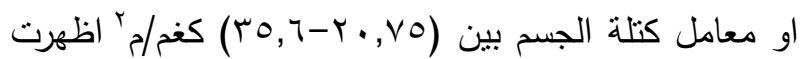
النتائج وجود زيادة معنوية في الكلوكوز الصيامي والكولسترول و HOMA عند النساء البدينات بالمقارنة مع النساء النحيفات وان هناك زيادة معنوية في مسنوى اللزوجة العالية للبروتين الدهني للنساء النحيفات عند مقارنتها مع النساء البدينات وان هناك علاقة طردية بين مؤشر او معامل كتلة الجسم مع الكلوكوز الصيامي والكولسترول والكلسريد 
Journal of Al-Nahrain University

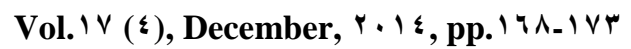

Science

الثلاثي والانسولين وHOMA والبروتين المرتبط سي عالي

الحساسية ومعدل النخر الهرمي والانترلوكين 7. 